\title{
Tangled up in mood
}

\section{Exploring Panará split ergativity*}

\author{
Bernat Bardagil-Mas \\ University of Groningen
}

The two primary goals of this article are to present data concerning the moodbased alignment split that can be observed in Panará pronominal clitics ${ }^{1}$ and to put forward a tentative formal analysis that can capture the motivations of such phenomena in the grammar. This paper aims to explore an approach to mood from a simple syntactic perspective, in which different sets of features active in the narrow syntax suffice to derive the case marking phenomena that are correlated with mood in Panará.

Keywords: ergativity, mood, functional categories, case, pronouns

\section{Introduction}

Ergative-accusative splits are anything but uncommon in the world's languages. However, an important majority of splits along tense-aspect-mood-evidentiality (TAME) categories are aspect-based (Comrie 1981; Dixon 1994; Silverstein 1976), to the point that mood-based splits are in fact barely recognized (Coon 2013). Panará presents one such system: the synthetic morphology that indexes participants on the verb is ergative in realis mood and accusative in irrealis. Mood, along with other TAME categories, has been extensively discussed in the literature. In this paper, mood is approached using the INFL system proposed by Ritter \& Wiltschko (2014), with some modifications that allow us to derive both the motivation of the split and the reason why it is specifically mood that is connected to it.

\footnotetext{
* This paper is based on Panará data collected during fieldwork in Nãsepotiti in 2014. I would like to thank my generous Panará informants, especially Perankô Panará and Seakiã Panará. I salute the audiences of various colloquia where the ideas developed here have been presented: WSCLA 20, TIN-Dag, and the Groningen Syntax Seminars.
}

1. The label clitic is used here not as a theoretical primitive but as a descriptive term. 


\section{The language}

Panará is a Jê language spoken in Brazilian Amazonia, in the basin of the Xingu river. The Panará occupied an extensive area in the north of Mato Grosso and the south of Pará before the government made contact with them in 1973, at which time they numbered approximately 700 individuals (Ewart 2008). Those Panará were in fact the surviving members of the so-called Southern Cayapó (Giraldin 1997), a group of Brazilian natives that had highly violent encounters with the colonial and neo-colonial Brazilian societies in the Goiás and Minas Gerais area, and were considered to be extinct at the beginning of the 20th century.

During the 1990s, after spending 20 years in the Xingu Park, they succesfully established a new village in their demarcated indigenous land on the banks of the Iriri Novo river, near the town of Guarantã do Norte in the state of Mato Grosso. The current population of Panará speakers is considered to be of around $500,{ }^{2}$ all of whom live in the three villages inside the Panará Indigenous Land.

Panará is closely related to the other Northern Jê languages Apinajé, Kĩsêdjê, Mẽbengokre and Timbira, but it also shows similarities with the extant central Jê languages Xavante and Xerente. As opposed to the strongly verb-final structure of other Northern Jê languages, Panará XPs have a very free positioning with respect to the verb and can be easily ommited: in naturalistic data collected and analized by Dourado (2001), approximately $50 \%$ of all sentences consist of just the verb, preceeded by a series of optional morphemes that index all arguments, as well as TAME categories, directionality, reciprocity and reflexivity. All of these morphemes, and also incorporated elements such as nouns and postpositions, occur in an immediately preverbal position.

\section{The allomorphy of case marking}

This section presents and discusses data on Panará case-marking strategies. Free nominals and pronouns present a consistent ergative marking independently of the tense, aspect, mood or evidentiality properties in the clause. Among direct cases, only ergative is morphologically marked (with hẽ). Absolutive is unmarked.

2. Instituto Socioambiental. Povos Indígenas no Brasil (http://pib.socioambiental.org). 
All oblique cases are marked by means of postpositions, ${ }^{3}$ though see (2) for cases where these postpositions are incorporated to the predicate. ${ }^{4}$

(1) Kupêrihẽ $t i=\quad r a=\quad \tilde{i} k w \hat{a}-r i \quad i k j \tilde{e}$. Kupêri ERG 3sG.ERG 1sG.ABS catch-PRF 1sG 'Kupêri caught me'

(2) Nãkã re= ho=pa-ri îkjẽ hẽ kârijô ho. snake 1sG.ERG INS kill-PRF 1sG ERG tobacco INS 'I killed a snake with tobacco'.

(3) $\tilde{I} k j \tilde{j} j y=r a=t \tilde{e}$. 1SG REAL 1sG.ABS fall 'I fell down'

The prosodically bound elements that index participants do not present a morphological variance with respect to the verbal features of the clause and their presence, albeit common, is not obligatory:

(4) Pukjora hẽ (ti=) ku-ri apjã.

Pukjora ERg (3sG.ERG) eat-PRF turtle

'Pukjora ate a turtle'.

This places them closer to the behaviour of doubled pronominal clitics rather than canonical agreement affixes (Corbett 2006). Nevins (2011) specifically considers invariance to tense $\mathrm{e}^{5}$ among the strongest defining properties of clitics as opposed to agreement morphology. Pending a detailed study on the specific behaviour of these morphemes, we will adopt the hypothesis, also defended by Dourado, that these are weak pronominals and not agreement affixes.

The pronominal clitics always present an immediately preverbal distribution, and this string of morphemes is always preceded by the $j y$ and $k a$ morphemes that correlate with mood differences (discussed in more detail in Section 4). While the pattern of the pronominal clitics in the examples above follows the ergative alignment of free nominals, in irrealis clauses a separate paradigm is used to index

3. Panará postpositions are: ablative, allative, benefactive, comitative, dative, ergative, inessive, instrumental-comitative, locative, malefactive.

4. The abbreviations used in this paper are: $1=$ first person, $2=$ second person, $3=$ third person, $\mathrm{ABL}=$ ablative, $\mathrm{ABS}=$ absolutive, $\mathrm{ACC}=$ accusative, $\mathrm{AUX}=$ auxiliary, $\mathrm{CAUS}=$ causative, $\mathrm{CNJ}=$ conjunction, $\mathrm{ERG}=$ ergative, $\mathrm{INESS}=$ inessive, $\mathrm{INS}=$ instrumental, $\mathrm{IRR}=$ irrealis, $\mathrm{LOC}=$ locative, $\mathrm{NOM}=$ nominative, $\mathrm{PL}=$ plural, $\mathrm{POSS}=$ possessive, $\mathrm{PRF}=$ perfect, $\mathrm{Q}=$ question particle, $\mathrm{REAL}=$ realis, $\mathrm{SG}=$ singular.

5. Or rather, invariance to the content of INFL, as will become relevant by the end of the paper. 
subjects, both transitive and intransitive, while the same absolutive paradigm is used for a second participant, but is in this mood limited to direct objects. We thus find a nominative and an accusative in the alignment of clitics in irrealis clauses.

(5) a. Pykôma $k a$ he $k a=t i=\quad r=\quad i s y-r i \quad i k j \tilde{e}$.

tomorrow 2SG ERG IRR 2SG.NOM 1SGABS hit-PRF 1SG

'Tomorrow you will hit me.'

b. Ka $k a=t i=\quad$ kre kowmã krekiã amã.

2SG IRR 2sG.NOM sing now night LOC

'You are going to sing tonight.'

These weak pronominals and their absolutive/ accusative, ergative and nominative paradigms are presented below.

Table 1. Weak pronominals

\begin{tabular}{lllll}
\hline & & ABS/ACC & ERG & NOM \\
\hline Singular & 1 & ra, $\mathrm{r}$ & $\mathrm{re}, \mathrm{ri}$ & $\varnothing$ \\
& 2 & $\mathrm{a}, \mathrm{k}$ & $\mathrm{ka}$ & $\mathrm{ti}$ \\
\multirow{3}{*}{ Plural } & 3 & $\varnothing, \mathrm{s}$ & $\mathrm{ti}$ & $\mathrm{ti}$ \\
& 1 & $\mathrm{ra}$ & $\mathrm{ne}$ & $\mathrm{ti}$ \\
& 2 & $\mathrm{ri}(\mathrm{a})$ & kari(a) & tiria \\
\multirow{3}{*}{ Dual } & 3 & ra & ne & $\varnothing$ \\
& 1 & ramẽ & ri/remẽ & mẽ \\
& 2 & amẽ & kamẽ & timẽ \\
& 3 & mẽ & timẽ & timẽ \\
\hline
\end{tabular}

For completeness, the strong pronoun paradigm is also given:

Table 2. Strong pronominals

\begin{tabular}{lll}
\hline & & Bare form \\
\hline Singular & 1 & îkjẽ \\
& 2 & ka \\
& 3 & mara \\
Plural & 1 & ikjẽmera \\
& 2 & kamera \\
& 3 & maramera \\
Dual & 1 & ikjẽra \\
& 2 & kara \\
& 3 & marara \\
\hline
\end{tabular}


A comparison of the forms in the two tables reveals quite clearly that person, dual and plural morphemes are different morphological units. Interestingly, plural is dual plus something else. In the clitic paradigm we find a clitic dedicated allomorph of dual $r a, m \tilde{e}$, which should not be confused with plural $m e .^{6}$ The number morphemes are not exclusive to the weak and strong pronouns: as seen in (6) they are also used with substantives.

(6) Mãmã pêj negromera. Africamera jy= ho= ra= pô Brasil CNJ ABL black-PL Africa-PL REAL CAUS 3PL.ABs come Brazil pârikâ amã nãkio tâti ho. ship LOC sickness hard INS 'Then the Blacks. The Africans were brought to Brazil in ships with nasty diseases.'

The suffixed morphemes that mark NPs for dual and plural present an ergative allomorph marked with /ã/, rã and merã respectively (7b). Plural ergative noun phrases that lack these two suffixes are still marked with hẽ (7c):

(7) a. Suasiramera $r a=$ to. boar-PL 3PL.ABs leave 'The boars went away.'

b. Suasĩramerã ne= ku-ri. boar-PL.ERG 3PL.ERG eat-PRF 'The boars ate.'

c. Suasĩra inkjêti hẽ ne= ku-ri. boar many ERG 3PL.ERG eat-PRF 'A lot of boars ate.'

As can also be seen in Tables 1 and 2, the most solid synchretism across the weak and strong pronominal forms is the 2sG $k a$, which appears as both the 2sG strong pronoun and the 2sG.ERG clitic. Unexpectedly, the irrealis mood particle is also $k a$, as discussed in Section 4.

\section{Panará mood}

In the existing literature on Panará (Dourado 2001, 2004), two morphemes have been interpreted as overt morphological marking of mood: the $j y$ prefix that appears with intransitive verbs in the realis mood (8a), and the $k a$ prefix found in

6. Oral and nasal vowels are separate phonemes in Panará, rather than allophones resulting from nasalization processes: /pay/ "to walk", /pã/ "small". 
the irrealis mood, both with intransitive (9a) and transitive verbs (9b). Irrealis is often translated as future, but other uses exist, such as in example (9c). Realis is normally translated as a non-future non-modal clause.

(8) a. Pôka jy= aprĩpe.

Pôka REAL sad

'Pôka is sad.'

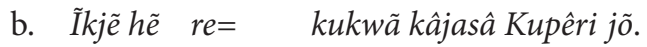

1sG ERG 1sG.ERG break knife Kupêri Poss

'I broke Kupêri's knife'

(9) a. İkjẽ ka=kre kowmã krekiã amã.

1SG IRR sing today night LOC

'I am going to sing tonight.'

b. Pykôma marahẽ $k a=t i=a=$ sisy-ri ka.

tomorrow 3SG ERG IRR 3NOM 2ABS hit-PRF 2.SG

'Tomorrow he will hit you.'

c. Ka=ti= ró kypa amã.

IRR 3SG.NOM fall ground INESS

'It fell to the ground.' (Pretending to drop a stone.)

As discussed above, Panará clitics appear with an ergative distribution in realis and an accusative one in irrealis, even though free nominals present an ergative marking regardless of a clause's mood. The remainder of this paper will advance an analysis of mood in Panará that can accomodate the clitic alignment split.

\subsection{Mood: Anchoring category}

As noted by various authors (Dourado 2001; Rodrigues 1999; Salanova 2011), Panará is the most divergent language in the Northern Jê branch: among others, it lacks the verb-final constituent order typical of Northern Jê, it has a rich morphology that indexes participants on the predicate head, it has a system of noun classifiers, and it presents a productive serial verb construction. It would appear that Panará is in the process of moving towards a polysynthetic structure, after reanalysing the Northern Jê verb-final independent clause in (10a) (Alves 2010; Nonato 2013; Oliveira 2005; Salanova 2007) as the verb inflection domain (10b):
a. $B a$
$a$
pumũ.
1sG.NOM 2sG.ACC see
'I see you.'
b. İkjẽ hẽ $[r e=\quad k=$ anpũ $k a$.
1 SG ERG 1SG.ERG 2SG.ABS see 2SG
'I see you.'

(Mẽbengokre) 
The Panara pronominal clitics correspond, then, to the strong pronouns in other Jê languages, like $b a$ in (10a). Turning to the role played by realis and irrealis mood in the Panará clause, we will propose in this section that, in Panará, mood can be argued to be a functional category ${ }^{7}$ that corresponds to Tense in more familiar languages. Ritter \& Wiltschko $(2009,2014)$ challenge the notion of Tense as a grammatical element that is obligatorily present also in languages in which the obligatory morphological marking does not correspond to temporality but to notions like location or person. In a language such as Panará the marking of tense is not contrastive (11), while a different category (mood) is obligatorily expressed and seems to trigger the marking of case in the verb inflection domain.

(11) a. $J y=$ ra $=$ kwy ka jõ kukre tã.

REAL 1sG.ABS go 2sG POss house

'I go to your house.'

b. Akasua $j y=r a=$ pô inkĩ. yesterday REAL 1sG.ABS arrive well 'Yesterday I had a good trip.'

c. $K a=t i=\quad k=\quad$ üpa nãkã hẽ?

IRR 3SG.ERG 2sG.ABS fear snake ERG 'Are you afraid of snakes?' (Would a snake scare you?)

d. Pykôma $\mathrm{ka}=\mathrm{ti}=\mathrm{s}=$ ikâ-ri mara. tomorrow IRR 2SG.ERG 3SG.ABS hit-PRF 3SG 'Tomorrow you will hit him.'

As opposed to realis, irrealis mood does not assert the actuality of the event depicted by the clause. Rather than assuming that an unobserved Tense category is present in Panará, the data lead us to think that Mood is in fact the category that plays that role. Just what is this role?

Ritter and Wiltschko (2014) propose, instead of Tense, an INFL category with the function of deictically anchoring the utterance by relating it to the event situation. Thus, INFL is an anchoring category, which can be mediated by a substantive content such as Tense, but also Person or Location. At the core of the anchoring function of INFL is the notion of coincidence, a "definition of spatial, temporal and identity relations". In Ritter and Wiltschko's system this is formalized via an unvalued coincidence feature [ucoin] on INFL that needs to be valued by the marking of the language-specific substantive content on INFL for the derivation not to crash.

7. As has been proposed, in Kĩsêdjê (Nonato 2013) mood would also instantiate finiteness in independent clauses. 
Mirroring the schematized articulation of Tense in Ritter and Wiltschko's INFL system, realis Mood would assert that the event actuality coincides with the utterance actuality, valuing [ucoin] as [+coin] (12), whereas irrealis would assert that the event actuality does not coincide with the utterance actuality, and the coincidence feature would be valued as [-coin] (13).

(12)

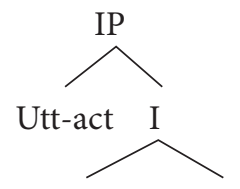

INFL Ev-act

[+coin]

realis

(13)

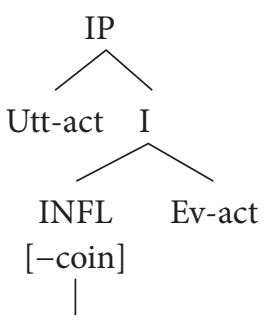

irrealis

\section{Towards an analysis of mood}

The depiction of Panará realis/ irrealis Mood mirroring Ritter and Wiltschko's present/ non-present Tense, however, is not completely satisfactory, as it makes no predictions regarding the alignment split in the clitic paradigm. The Panará data suggest that this mood-filled INFL is also responsible for the accusative pattern found in the clitic paradigm of Panará only in irrealis clauses. This section proposes an alternative derivation of Mood INFL that successfully predicts the alignment split.

The synchretism pointed out above (cf. 3) between irrealis $k a$ and second person $\mathrm{ka}$ gives us a clue to a modification of this approach that will allow us to make the right predictions. We will first look at pronouns and Dutch imperatives, and we will go back to the Mood INFL of Panará. 


\subsection{Location deixis}

We will assume a simple deixis system with a referential distinction between the speaker and the addressee, proximate and distal (Levinson 1983), plus a neutral non-proximate non-distal type. If proximate coincides with the speaker, distal is "away from the speaker" and neutral precedes the speaker (Barbiers 2013), corresponding to first, second and third person in the system of person reference. We thus get the following schematic decomposition of persons:

Table 3. Person decomposition

\begin{tabular}{lll}
\hline First person & [person] & [proximate] \\
Second person & [person] & [distal] \\
Third person & [person] & \\
\hline
\end{tabular}

We further see this distal element in action in Dutch and German imperatives (Barbiers 2013). Both German and Dutch are verb second languages of the asymmetric type, presenting verb second constraints only in independent clauses, ${ }^{8}$ while subordinate clauses are verb final. In imperative clauses the two languages diverge: German can optionally license verb second constructions, whereas Dutch cannot. The analysis in Barbiers (2013) decomposes the second person element that is standardly assumed to be required in the $\mathrm{C}$ domain of imperative clauses (Bennis 2007) as a [person] feature and a [distal] feature. However, in Eastern Dutch dialects like North Brabantish the situation is less clear-cut. Unlike in standard Dutch, some fronting in imperatives is allowed. Unlike in German, only distal D-pronouns can be fronted, both argumental and adverbial ones.

Crucially, the presence of this [distal] feature within a three-way contrast is what seems to allow both distal D-pronouns and second person to license imperatives in North Brabantish. The emergence of a distal natural class across different grammar domains is what will allow us to go back to Mood in Panará with a slightly modified approach.

\subsection{Irrealis: Distal mood}

The substantive content of INFL is not the only element that can value the [ucoin] feature in the system proposed by Ritter \& Wiltschko (2014). One of the predictions of this separation of Tense from INFL is that INFL can occur dissociated from its substantive content. It seems indeed to be the case that the unvalued co-

8. With the exception of certain assertive verbs. 
incidence feature can be valued via different mechanisms, at least what Ritter \& Wiltschko present as predicate valuation and COMP-valuation.

In this paper we will consider that INFL is the projection of an element carrying the [ucoin] feature. ${ }^{9}$ In realis clauses, just like in Ritter \& Wiltschko (2014), the abstract pronominal situation argument that acts as the Utterance element is interpreted deictically as Tense, Location or, in our case, Mood.

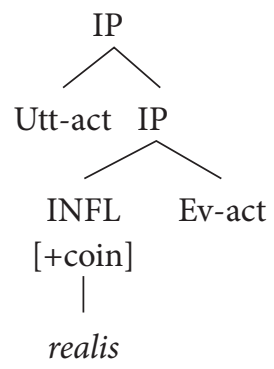

In irrealis clauses, the INFL projection is further merged with a [distal] element. ${ }^{10}$ We could assume that it has a pronominal nature, but it need not be the case. As a deictic element, [distal] will also be able to value the coincidence feature: "The only restriction on the substantive content of INFL is that it be suitable for establishing a relationship between the event and the utterance. This predicts that any type of deictic content will be appropriate for valuing [ucoin] in INFL." Just like embedding future irrealis infinitives do (Ritter \& Wiltschko 2014), the deictic [distal] element will value INFL as [-coin], asserting the non-coincidence of the utterance actuality introduced at the INFL level and the event actuality introduced inside the vP.

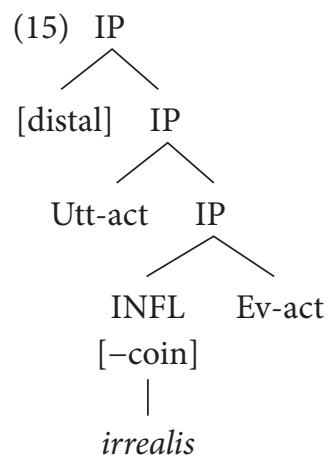

9. Our proposal diverges from the account by Ritter and Wiltschko in that we do not consider INFL an element of the functional spine.

10. For the sake of simplicity we keep the default generation of this Pro-sit element, which is merged with INFL and then coindexed with the [distal] element. 
It is then [distal] that irrealis has in common with second person (16). We propose that the [distal] merged in the INFL projection is spelled out in irrealis as $k a$, as well as in second person $k a$.

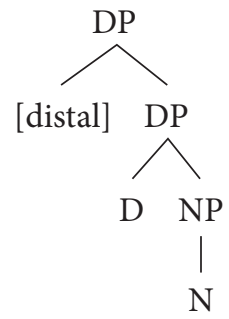

It could be the case that in future irrealis infinitives (17a) the element that values the coincidence feature in the embedded INFL as [-coin] is actually a [distal] feature in the matrix lexical verb (want, decide).

(17) a. In the morning, Konrad wanted to dance (in the afternoon).

b. In the morning, Mika started to dance (*in the afternoon). (Adapted from Ritter \& Wiltschko (2014))

A $L I N$ reviewer asks whether the prediction is that pronominal $k a$ can also value INFL as [-coin] in irrealis clauses. Notice, though, that the only way for a [distal] element to be merged with the projection of [ucoin]/INFL is for it to be introduced in what corresponds to a specifier of IP. The strong pronominal $\mathrm{ka}$ is already introduced within a DP licensed for case in its postverbal position, and a pronominal clitic $k a$ is the result of a postsyntactic operation, either via head-movement or as the spell-out of the dependent features on the predicate head.

\section{The alignment split}

Two major aspects of the mood-related phenomena in Panará are still unaddressed: the split ergative system in the weak pronominal paradigm, and the $j y$ element that appears in realis intransitive clauses.

We have argued that $k a$ corresponds to a mood-filled INFL, more specifically a spelled-out deictic [distal] feature that is merged with IP and values the coincidence feature of INFL. With respect to $j y$, we are led to consider it something else. We propose that it is an auxiliary that does not correspond to the anchoring category: there is thus no overt morphological marking for realis mood in Panará. Instead, $j y$ seems to be something similar to a light verb that appears in intransitive clauses, but only in realis mood. 
There are several reasons to think that this is the case. The different valuation mechanism of the coincidence feature in irrealis clauses would predict intervention effects like those that Ritter \& Wiltschko (2014) report in some cases of COMP-valuation, where negation is similarly not allowed to intervene between the valuing element and INFL.

The distribution of $k a$ and $j y$ is also different. While $j y$ is often omitted (18b) and could be claimed to appear more with certain verbs than with others, irrealis $k a$ is virtually obligatory.
a. Ajy a i ki $k a$ ?
Q REAL 2SG.ABS good 2SG
'Are you alright?'
b. Pa,ra iki pytĩsi.
yes 1sG.ABs good very
'Yes, I’m very good.'

Further work is needed to establish just how much this is the case, especially with a careful analysis of naturalistic texts.

\subsection{A quirky nominative}

We are finally in a position to offer an explanation of the Panará mood-based alignment split. In this language, Mood is the substantive content of INFL, an anchoring category with a defective nature represented with the [ucoin] feature. That is to say, INFL needs a deictic element in the clause to provide it with a feature that allows it to anchor an event to an utterance.

The accusative alignment of weak pronominals in irrealis clauses follows from the notion that case has a different connection with different types of coincidence valuation, just like English clauses can only license nominative case if INFL is valued by its substantive content (19a), but not via predicate valuation (19b).

(19) a. Paul arrived.

b. Paul wanted $\left({ }^{*}\right.$ he) to arrive.

In Panará, all weak pronominals that surface next to the verb bear initially morphological marking for the case assigned to the participants that they double. This is the marking that we see overtly in realis clauses. In irrealis clauses, the distalvalidated Mood manifests on the pronominal clitic most adjacent to it, be it the one doubling the ergative subject or the absolutive subject. 
(20) a. Mara $[j y \quad \varnothing=\quad k w y]$

3sg AUX 3sGNOM go

'He went.'

b. Mara $\left[\begin{array}{lll}k a & \boldsymbol{t} i= & k w y\end{array}\right]$

3SG IRR 3SGNOM go

'He will go.'

(21)

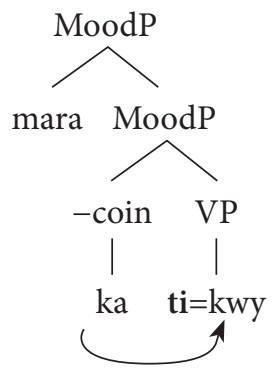

(22) a. Ka he $[k a \quad r a \quad s i s y \tilde{\imath} k j \tilde{e}]$

2sG ERG 2sG.ERG 1sG.ABS hit 1sG

'You hit me.'

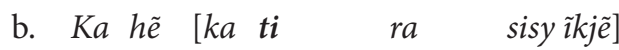

2SG ERG IRR 2SG.NOM 1sG.ABS hit 1sG

'You will hit me.'

(23)

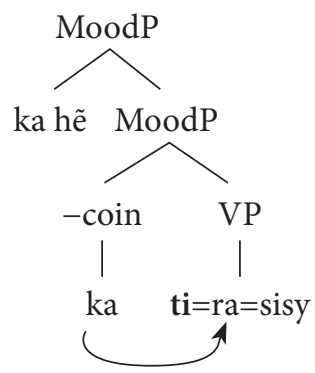

Nominative case in Panará clitics, then, looks like a morphological case that is assigned to the highest clitic pronoun in irrealis contexts. The case assignment mechanisms of the different types of Panará clauses are a question for further research, although we could suspect the broader structure of the INFL projection in irrealis clauses to be in part responsible. 


\section{Conclusion}

This initial analysis of the mechanisms underlying mood-related phenomena in Panará presents supporting data for the notion of an anchoring category that can be valued by diverse deictic elements. We have argued that mood is the substantive content of INFL in Panará, and we have explored ways in which the system advanced by Ritter and Wiltschko can also be an interesting explanatory tool when detached from the stipulation of a functional spine.

The accusative side of the alignment split of Panará weak pronouns seems to be an instance of morphological case, motivated by a [distal] feature that merges with INFL. The evidence examined in this paper thus suggests that there is no such split in the abstract case system of this language, and this would lead us to expect that Panará case is solidly ergative and does not present a rare mood-based alignment split after all.

However, Panará seems to lack so-called syntactically ergative behaviours in its extraction and control operations, which points out to an accusative structure beyond case-marking of free nominals. Further work is still necessary to understand what motivates Panará ergativity, and to clarify the connection between case assignment and anchoring categories and their substantive content.

\section{References}

Alves, Flávia de Castro. 2010. Evolution of alignment in Timbira. IJAL 76(4). 439-475.

Barbiers, Sjef. 2013. Geography and Cartography of the Left Periphery. The Case of Dutch and German Imperatives. In E. Carrilho, C. Magro \& X. Álvarez (eds.), Current approaches to limits and areas in dialectology, vol. 1, 267-292. Newcastle upon Tyne: Cambridge Scholars Publishing.

Bennis, Hans. 2007. Featuring the subject in Dutch imperatives. In Wim van der Wurff (ed.), Imperative Clauses in Generative Grammar. Amsterdam: John Benjamins.

DOI: $10.1017 / \mathrm{s} 0022226708005288$

Comrie, Bernard. 1981. Language Universals and Linguistic Typology: Syntax and Morphology. Chicago: University of Chicago Press.

Coon, Jessica. 2013. TAM Split Ergativity (Parts I-II). Language and Linguistics Compass 7(3). 171-200. DOI: $10.1111 /$ lnc3.12011

Corbett, Greville G. 2006. Agreement, 1st edn. Cambridge: Cambridge University Press.

Dixon, Robert M. W. 1994. Ergativity. Cambridge: Cambridge University Press.

DOI: $10.1017 / \mathrm{CBO} 9780511611896$

Dourado, Luciana Gonçalves. 2001. Aspectos morfossintáticos da língua Panará (Jê). Campinas: UNICAMP $\mathrm{PhD}$ thesis.

Dourado, Luciana Gonçalves. 2004. Ergatividade e transitividade em panará. In Francesc Queixalós (ed.), Ergatividade na amazônia II. CELIA. 
Ewart, Elizabeth. 2008. Seeing, Hearing and Speaking: Morality and Sense among the Panará in Central Brazil. Ethnos 73(4). 505-522. DOI: 10.1080/00141840802563949

Giraldin, Odair. 1997. Cayapó e Panará: luta e sobrevivência de um povo Jê no Brasil Central. Editora Unicamp.

Levinson, Stephen C. 1983. Pragmatics. Cambridge, England: Cambridge University.

Nevins, Andrew. 2011. Multiple agree with clitics: Person complementarity vs omnivorous 0. Natural Language \& Linguistic Theory 29(4). 939-971. DOI: 10.1007/s11049-011-9150-4

Nonato, Rafael. 2013. Clause-chaining, switch-reference and coordination. Cambridge, MA: Massachusetts Institute of Technology $\mathrm{PhD}$ thesis.

Oliveira, Christiane Cunha de. 2005. The language of the Apinajé people of Central Brazil. University of Oregon $\mathrm{PhD}$ thesis.

Ritter, Elizabeth \& Martina Wiltschko. 2009. Varieties of INFL: Tense, Location, and Person. In H. Broekhuis, J. Craenenbroek \& H. van Riemsdijk (eds.), Alternatives to cartography. Berlin, New York: Mouton de Gruyter.

Ritter, Elizabeth \& Martina Wiltschko. 2014. The composition of INFL. Natural Language \& Linguistic Theory 32(4). 1331-1386. DOI: 10.1007/s11049-014-9248-6

Rodrigues, Aryon. 1999. Macro-Jê. In R. M. W. Dixon \& A. Aikhenvald (eds.), The Amazonian languages. Cambridge University Press.

Salanova, Andrés Pablo. 2007. Nominalizations and aspect. Cambridge, MA: Massachusetts Institute of Technology $\mathrm{PhD}$ thesis.

Salanova, Andrés Pablo. 2011. Semántica causativa, sintaxis aplicativa. In F. Queixalós (ed.), Incremento de valencia en las lenguas amazónicas. Bogotá: Instituto Caro y Cuervo.

Silverstein, Michael. 1976. Hierarchy of features and ergativity. In R. M. W. Dixon (ed.), Grammatical categories in Australian languages, 112-171. Canberra: Australian National University.

Author's address

Bernat Bardagil-Mas

University of Groningen

Oude Boteringestraat 23, room 0012

9712 GC Groningen

The Netherlands

bbardagil@gmail.com 